\title{
In vitro fermentation of gum acacia - impact on the faecal microbiota
}

Article

Accepted Version

Alarifi, S., Bell, A. and Walton, G. (2018) In vitro fermentation of gum acacia - impact on the faecal microbiota. International Journal of Food Sciences and Nutrition, 69 (6). pp. 696-704. ISSN 1465-3478 doi:

https://doi.org/10.1080/09637486.2017.1404970 Available at https://centaur.reading.ac.uk/75203/

It is advisable to refer to the publisher's version if you intend to cite from the work. See Guidance on citing.

To link to this article DOI: http://dx.doi.org/10.1080/09637486.2017.1404970

Publisher: Informa Healthcare

All outputs in CentAUR are protected by Intellectual Property Rights law, including copyright law. Copyright and IPR is retained by the creators or other copyright holders. Terms and conditions for use of this material are defined in the End User Agreement.

\section{www.reading.ac.uk/centaur}

\section{CentAUR}

Central Archive at the University of Reading 
Reading's research outputs online 


\section{Title page}

2 In vitro fermentation of gum acacia - impact on the faecal microbiota

3 Sehad Alarifi, Alan Bell, Gemma Walton

4 Corresponding author Gemma Walton. Email address g.e.walton@ reading.ac.uk

5 Department of Food and Nutritional Sciences

$6 \quad$ PO Box 226

$7 \quad$ Whiteknights

$8 \quad$ Reading

$9 \quad$ RG6 6AP

10 Sehad Alarifi PhD student in University of Reading

11 Dr Alan Bell Lecturer in University of Reading

12 Dr Gemma Walton Lecturer in University of Reading

13

14

15

16

17

18

19

20

21

22 
Abstract

Interest in the consumption of gum acacia (GA) has been associated with beneficial health effects, which may be mediated in part by prebiotic activity. Two doses of GA and fructooligosaccharide (FOS) (1\% and 2\%) were tested for their efficacy over $48 \mathrm{~h}$ in $\mathrm{pH}$ - and temperature-controlled anaerobic batch cultures inoculated with human faeces. Samples were taken after $0,5,10,24$, and $48 \mathrm{~h}$ of fermentation. The selective effects of GA (increases in Bifidobacterium sp. and Lactobacillus sp.) were similar to those of the known prebiotic FOS. The $1 \%$ dose of substrates showed more enhanced selectivity compared to the $2 \%$ dose. The fermentation of GA also led to SCFA production, specifically increased acetate after 10, 24, and $48 \mathrm{~h}$ of fermentation, propionate after $48 \mathrm{~h}$, and butyrate after 24 and $48 \mathrm{~h}$. Additionally, FOS led to significant increases in the main SCFAs. These results suggest that GA displays potential prebiotic properties.

\section{Key words}

Gum acacia (GA); Prebioitcs; Intestinal bacteria; In vitro fermentation. 
The colon has the most abundant and diverse population of bacteria in the human body and is inhabited by around 1000 different bacterial species, which can reach $10^{14}$ colony-forming units CFU (Gibson and Roberfroid 1995). The human microbiome is a complex and dynamic system that plays an important role in human health (Eckburg et al. 2005, Kaiko and Stappenbeck 2014). By interacting with consumed material, colonic inhabitants ferment undigested food and secrete end products such as gases and SCFA (Gibson and Roberfroid 1995). Moreover, the composition of the bacterial population may shift, resulting in increases in bacteria associated with beneficial effects. Inulin and FOS are known prebiotics that are commercially used worldwide (Mandalari et al. 2008, Steer et al. 2003). A prebiotic is defined as "a selectively fermented ingredient that results in specific changes in the composition and/or activity of the gastrointestinal microbiota, thus conferring benefit(s) upon host health" (Gibson et al. 2010).

GA is derived from acacia trees of the Leguminosae family. It is an arabinogalactan protein complex with an approximate molecular weight of 350-850 K Da (Mahenran.T et al. 2008,, Williams and Phillips 2000. ). It is a polysaccharide consisting of branched chains of (1-3) linked $\beta$-D galactopyranosyl units. Side chains, 2 to 5 units in length, are attached by (1-6) rhamnopyranosyl, $\beta$-D-glucuronopyranosyl, and 4-O-methyl- $\beta$-D-glucuronopyranosyl units (Bliss et al. 2013). GA is widely used in the pharmaceutical and food industries as an additive , a stabilising, thickening, and an emulsifying agent (Dauqan and Abdullah 2013) (Verbeken et al. 2003).

GA is not digestible in the small intestine and is fermented in the large intestine, and has been observed to lead to increases in Bifidobacterium spp. (Calame et al. 2008) (Terpend et al. 2013) (Marzorati et al. 2015). Bifidobacterium spp. have been shown to inhibit the growth of 
pathogenic bacteria, modulate the immune system, and produce SCFAs, which reduce the $\mathrm{pH}$ in the colon, imparting antimicrobial activity against pathogens (Gibson and Roberfroid 1995). A variety of GA doses ranging from 5 to $40 \mathrm{~g} / \mathrm{d}$ have been reported to be effective in increasing Bifidobacterium spp. and Lactobacillus spp. populations (Calame, Weseler, Viebke, Flynn and Siemensma 2008, Cherbut et al. 2003). These lines of evidence indicate that GA has bifidogenic potential in healthy humans. However optimal effective doses have not been defined. The results from most previous studies cannot be directly compared, as different methodologies, population groups, and types of GA have been studied. In addition, high daily doses of GA could result in the manifestation of adverse effects such as mild diarrhoea and bloating (Babiker et al. 2012).

In vitro batch culture systems are used to simulate the main physiological and microbiological processes in the distal colon and can be combined with metabolic and molecular analyses. Therefore, the aim of the following study was to investigateof the impact of two GA doses on the faecal microbiota following $48 \mathrm{~h}$ fermentation in $\mathrm{pH}$-controlled batch culture systems, as compared to the known prebiotic FOS.

\section{Material and methods}

\section{Substrates}

GA (KLTA-MF-Kerry Ingredients, U.K.) was in spray dried form as a water soluble, freeflowing powder (food-grade). Table (1) shows the composition of GA used in this study, dietary fibre were analysed by Campden BRI Laboratories (AOAC method 991.43). The FOS used was Orafti ${ }^{\circledR}$ P95 (Beneo, Belgium) extracted from chicory root. 
[Table 1 near here].

\section{In vitro Upper Gut Digestion}

101

102

103

104

105

106

107

108

109

110

111

112

113

114

115

116

117

118

119

120

121

Upper gut digestion was performed according to the protocol of Mills et al.(2008) (Mills et al. 2008). Briefly, $60 \mathrm{~g}$ of GA powder was added to $150 \mathrm{ml}$ of distilled water and the solution mixed with $20 \mathrm{mg} \alpha$-amylase in $6.25 \mathrm{ml} \mathrm{CaCl} 2(1 \mathrm{mM})$ and incubated on a shaker at $37{ }^{\circ} \mathrm{C}$ for 30 minutes. This simulated the initial oral digestion. Subsequently, $2.7 \mathrm{~g}$ of pepsin in $25 \mathrm{ml}$ of $\mathrm{HCl}(0.1 \mathrm{M})$ was used to facilitate gastric breakdown of the sample. The $\mathrm{pH}$ was then reduced progressively to 2 by adding $6 \mathrm{M} \mathrm{HCl}$, before incubating on a shaker at $37^{\circ} \mathrm{C}$ for 2 hours. A further $560 \mathrm{mg}$ of pancreatin and $3.5 \mathrm{~g}$ of bile, in $125 \mathrm{ml}$ of $\mathrm{NaHCO}_{3}$ solution, was added to simulate the effect of the small intestine on the gum sample. The $\mathrm{pH}$ was increased to 7 by adding $\mathrm{NaOH}(6 \mathrm{M})$ and the resulting suspension incubated on a shaker at $37^{\circ} \mathrm{C}$ for 3 hours. Samples were transferred to cellulose dialysis membrane (1 KDa molecular weight), purchased from Cheshire biotech Cheshire, UK, and dialysed against $10 \mathrm{Mm}$ of $\mathrm{NaCl}$ solution at $5^{\circ} \mathrm{C}$ to remove low molecular mass digestion products. After 15 hours, the dialysis fluid was changed and dialysis continued for additional $2 \mathrm{~h}$. The sample within the dialysis tubing was freeze dried (5 days) prior to use in batch culture systems. The final sample was weighed and GA loss in the upper gut was subsequently calculated.

\section{Faecal sample preparation}

Faecal samples were obtained from three healthy volunteers (31- 35 years of age), who had not been consuming antibiotics for at least 6 months before the study and had no history of gastrointestinal disease. Volunteers were not consumers of probiotic or prebiotic supplements. Samples were prepared on the day of the experiment and within 1 hour of production and were diluted to $1: 10$, w/v in anaerobic phosphate buffer $(0.1 \mathrm{M} ; \mathrm{pH} 7.4)$. 
Samples were homogenised in a stomacher for $2 \mathrm{~min}$, the resulting slurry was inoculated into batch culture fermenters.

\section{Batch cultures}

Three independent batch culture experiments were carried out using faeces from a different donor each time. Vessels were autoclaved and then aseptically filled with $135 \mathrm{ml}$ of basal medium (peptone water $(2 \mathrm{~g} / \mathrm{l})$, yeast extract $(2 \mathrm{~g} / \mathrm{l}), \mathrm{NaCl}(0.1 \mathrm{~g} / \mathrm{l}), \mathrm{K}_{2} \mathrm{HPO}_{4}(0.04 \mathrm{~g} / \mathrm{l})$, $\mathrm{KH}_{2} \mathrm{PO}_{4}(0.04 \mathrm{~g} / \mathrm{l}), \mathrm{NaHCO}_{3}(2 \mathrm{~g} / \mathrm{l}), \mathrm{MgSO}_{4} \bullet 7 \mathrm{H}_{2} \mathrm{O}(0.01 \mathrm{~g} / \mathrm{l}), \mathrm{CaCl}_{2} \bullet 6 \mathrm{H}_{2} \mathrm{O}(0.01 \mathrm{~g} / \mathrm{l})$, tween $80(2 \mathrm{ml} / \mathrm{l})$, hemin $(50 \mathrm{mg} / \mathrm{l})$, vitamin $\mathrm{K} 1(10 \mathrm{ml} / \mathrm{l})$, L-cysteine $(0.5 \mathrm{~g} / \mathrm{l})$, bile salts $(0.5 \mathrm{~g} / \mathrm{l}), 0.5$ $\mathrm{ml} / \mathrm{l}$ of $10 \%$ cysteine $-\mathrm{HCl}$, resazurin $(1 \mathrm{mg} / \mathrm{l}))$. Vessels were left overnight with nitrogen pumping $(15 \mathrm{~mL} / \mathrm{min})$ through the vessel to provide an anaerobic environment. Before addition of faecal slurry, temperature of basal medium was set at $37{ }^{\circ} \mathrm{C}$ and $\mathrm{pH}$ was maintained at 6.7-6.9 using a pH meters (Electrolab $\mathrm{pH}$ controller, Tewksbury, UK) by the addition of $0.5 \mathrm{M} \mathrm{HCl}$ or $0.5 \mathrm{M} \mathrm{NaOH}$. The vessels were stirred using magnetic stirrers. $1.5 \mathrm{~g}$, $3 \mathrm{~g}(1 \% \mathrm{w} / \mathrm{v})$ of FOS and $0.6 \mathrm{~g}$ and $0.3 \mathrm{~g}(1: 10 \mathrm{w} / \mathrm{v})$ of pre-digested GA (taking to account the loss of substrate in the upper gut from the predigestion) were added to the vessel $1 \%$ and doubling the dose $2 \%$ just prior to the addition of $15 \mathrm{ml}$ of faecal slurry $(10 \% \mathrm{w} / \mathrm{w})$. The vessels were left for $48 \mathrm{~h}$, with samples taken at 0, 5, 10, 24 and 48h. Samples were centrifuged in preparation for GC analysis, or prepared for microbial enumeration by FISH.

\section{Florescence in situ hybridisation (FISH) analysis}

To asses diffrences in bacterial population, samples hybridised as described by Daims et al., 1999 (Daims et al. 1999). A sample of 375- $\mu$ l obtained from each vessel was fixed for four hours $4^{\circ} \mathrm{C}$ in $1125 \mu \mathrm{L}(4 \% \mathrm{w} / \mathrm{v})$ paraformaldehyde. Fixed samples were then centrifuged at 11,337g (Eppendorf centrifuge minispin, Eppendorf, UK) at room temperature for 5 minutes. The supernatant removed and discarded. The pellet was resuspended in $1 \mathrm{ml}$ of cold $1 \times \mathrm{PBS}$ 
by aspirating carefully using a pipette. This step was conducted twice. The washed cells were suspended in $150 \mu \mathrm{L}$ of cold $1 \times \mathrm{PBS}$, then $150 \mu \mathrm{L}$ of ethanol $(99 \%)$ was added and the samples were stored at $-20^{\circ} \mathrm{C}$.

The oligonucleotide probes used were commercially synthesised and labeled with the fluorescent dye Cy3 (Sigma Aldrich Co. Ltd. UK). These were: Bif164 for Bifidobacterium spp. (BIF), Lab158 for Lactobacillus/enterococcus (LAB), Ato291 for Atopobium cluster (Atopobium, Coriobacterium, Collinsella spp.) (ATO), Chis 150 for Clostridium histolyticum group (CHIS) Erec 482 for Eubacterium rectale - Clostridium coccoides group (EREC), Bac 303 for Bacteroides-Prevotella group (BAC). EUB 338 mixture consisting of EUB338, EUB338II and EUB338III for total bacteria (Total) see Table (2). For the hybridisation $20 \mu$ L of diluted sample was pipetted onto a teflon poly-L-lysine-coated six-well slide (Tekdon Inc., Myakka City, FL). The samples were dried onto the slides at $46-50^{\circ} \mathrm{C}$ for 15 minutes and after that dehydrated in an alcohol series 50, 80, and 96\%. The ethanol was allowed to evaporate from the slides before hybridisation buffer was added. A probe/hybridization buffer mixture $(5 \mu \mathrm{L}$ of a $50 \mathrm{ng} / \mu \mathrm{L}$ stock of probe plus $50 \mu \mathrm{L}$ of hybridization buffer). To permeabilise the cells for use with probes Bif164 and Lab158, samples were treated with $20 \mu$ L of lysozyme at room temperature for $15 \mathrm{~min}$ before being washed briefly for $2-3$ seconds in water and then dehydrated in the ethanol series. Then slides were placed in hybridisation oven for 4 hours (ISO 20 oven, Grant Boekel). For the washing step, slides were placed in 50 $\mathrm{ml}$ of washing buffer $\left(\begin{array}{lllllllll}0.9 & \mathrm{M} & \mathrm{NaCl} & 0.02 & \mathrm{M} & \mathrm{Tris} / \mathrm{HCl} & (\mathrm{pH} & 8.0\end{array}\right), 0.005 \quad \mathrm{M}$ ethylenediaminetetraacetic acid (EDTA) solution ( $\mathrm{pH}$ 8.0, Table (2), warmed at the appropriate temperature for each probe and $20 \mu \mathrm{L}$ of 4;6-diamidino-2-phenylindole di hydrochloride (DAPI) was added to the washing buffer for $15 \mathrm{~min}$. They were then briefly washed (2-3 s) in ice-cold water and dried under a stream of compressed air. Five microliters of ProLong Gold antifade reagent (Invitrogen) was added to each well and a coverslip 
applied. Slides were stored in the dark at $4{ }^{\circ} \mathrm{C}$ until cells were counted under a Nikon E400

172 Eclipse microscope. DAPI stained cells were examined under UV light, and a DM510 light filter was used to count specific bacteria hybridised with the probes. For each slide, 15 random different fields of view were counted.

$175 \quad$ [Table 2 near here].

\section{Preparation sample for short chain fatty acids}

177 Samples were extracted and derivatised as previously described (Richardson et al. 1989). 178 Samples were defrosted and $1 \mathrm{ml}$ of each sample or standard solution was transferred into a labeled $100 \mathrm{~mm} \times 16 \mathrm{~mm}$ glass tube with the internal standard of $50 \mu 1$ of 2 - ethyl butyric acid (0.1M). $0.5 \mathrm{ml}$ concentrated $\mathrm{HCl}$ and $2 \mathrm{ml}$ of diethyl ether was added to each glass tube and samples vortexed for $1 \mathrm{~min}$. samples were centrifuged at $2000 \mathrm{~g}$ for $10 \mathrm{~min}$ (SANYO MSE Mistral 3000i; Sanyo Gallenkap PLC, Middlesex, UK). The diethyl ether (the upper layer) was transferred in a new glass tube. A second extraction was conducted by adding $1 \mathrm{ml}$ of diethyl either to the sample followed by vortex and centrifugation. $400 \mu$ of pooled ether extract and $50 \mu \mathrm{N}$-(tert-butyldimethylsilyl)-N-methyltrifluoroacetamide (MTBSTFA) was added in a GC screw-cap vial. Samples were heated at $80^{\circ} \mathrm{C}$ for 20 minutes and then left at room temperature for 48 hours to allow lactic acid in the samples to completely derivatise.

A 5890 SERIES II Gas Chromatograph (Hewlett Packard, UK) using an Rtx-1 10m×0.18mm column with a $0.20 \mu \mathrm{m}$ coating (Crossbond 100\% dimethyl polysiloxane; Restek, Buckinghamshire, UK) was used for analysis of SCFA. Temperatures of injector and detector were $275^{\circ} \mathrm{C}$, with the column programmed from $63^{\circ} \mathrm{C}$ for 3 minutes to $190^{\circ} \mathrm{C}$ at $10^{\circ} \mathrm{C}$ min- 1 and held at $190^{\circ} \mathrm{C}$ for 3 minutes. Helium was the carrier gas (flow rate $1.2 \mathrm{ml} \mathrm{min}-1$; head pressure $90 \mathrm{MPa})$. A split ratio of 100:1 was used. The standard solution contained $(\mathrm{mM})$ : sodium formate, 10; acetic acid, 30; propionic acid, 20; isobutyric acid, 5; n-butyric acid, 20; 
iso-valeric acid, 5; n-valeric acid, 5; sodium lactate, 10; sodium succinate, 20. The sample was injected onto the column, which was maintained at $140{ }^{\circ} \mathrm{C}$ for the first 5 minutes, temperature of the column was increased over 5 minutes to $240{ }^{\circ} \mathrm{C}$. To maintain appropriate calibration after injection of every 20 samples an external standard solution, with known concentrations of SCFAs was injected. Peaks and response factors within samples were calibrated and calculated using ChemStation B.03.01 software (Agilent Technologies, Cheshire, UK).

\section{Statistical analysis}

GA and FOS both doses were tested in batch cultures inouculated with faecal samples collected from three individial donors in three separate experiments. The $\log 10$ numbers of specific bacteria were expressed as mean values and standard diviation. Statistical tests were performed using SPSS, (SPSS Statistical Software, Inc., Chicago, IL, USA), version 18.0 A repeated measures one-way analysis of variance ANOVA to test the effect of time with the factor subjects, with five levels $(0 \mathrm{~h}, 5 \mathrm{~h}, 10 \mathrm{~h}, 24 \mathrm{~h}$ and $48 \mathrm{~h})$ and to assess the significant differences between the two subjects in the same time points. Significant differences between times point were represented by “*” $\mathrm{p}<0.05$, “**” $\mathrm{p}<0.01$ and “***” $\mathrm{p}<0.001$.

\section{Results}

\section{Effects of different doses of GA and FOS on human faecal bacteria}

To assess the impact of GA on the intestinal microbiota composition, $\mathrm{pH}$-controlled, anaerobic, faecal batch cultures were conducted using FOS as a positive prebiotic control. Samples were taken after $0,5,10,24$, and $48 \mathrm{~h}$ of fermentation. Bacteria were enumerated by FISH. 
The fermentation of GA at the $1 \%$ dose led to increased numbers of Bifidobacterium spp. after 5, 10, and $24 \mathrm{~h}$ of fermentation and of Lactobacillus spp. after 5 and $24 \mathrm{~h}$ compared with the levels at $0 \mathrm{~h}$, as shown in Tables (3a, 3b). However, a small but statistically significant drop in Bifidobacterium spp. compared with the negative control was seen after $24 \mathrm{~h}$ $(7.53 \pm 0.10,7.22 \pm 0.37$ GA $1 \%)(7.46 \pm 0.21,7.64 \pm 0.29$ control $)$.

Fermentation of $2 \%$ GA a led to a significant increase in Bifidobacterium spp. after 5 and 10 h compared with the baseline levels (time $0 \mathrm{~h}$ ). Total bacteria increased after the fermentation of $2 \% \mathrm{GA}$ for $48 \mathrm{~h}$ compared with the baseline levels.

The $1 \%$ dose of FOS led to a significant increase in Bifidobacterium spp. after $5 \mathrm{~h}$ compared with baseline $(7.39 \pm 0.21,7.83 \pm 0.06)$. Lactobacillus spp. increased following fermentation of FOS at a dose of $1 \%$ at 5, 10, and $24 \mathrm{~h}$. The $2 \%$ FOS dose significantly increased Bifidobacterium spp. numbers after $24 \mathrm{~h}$ compared with the negative control $(8.12 \pm 0.16$, $7.78 \pm 0.17)$ and after $5 \mathrm{~h}$ compared with baseline levels $(\mathrm{p}=0.03)$, whereas an increase in Lactobacillus spp. was observed after $5 \mathrm{~h}(7.75 \pm 0.14,7.29 \pm 0.07)$ and $24 \mathrm{~h}(7.51 \pm 0.10$, $7.29 \pm 04)(p=0.01$ and 0.02 , respectively) compared with the negative control.

The number of bacteria in the $C$. histolyticum group decreased after fermentation of $1 \%$ FOS and $1 \%$ GA for 5 and $10 \mathrm{~h}$, respectively, compared with the baseline levels. Additionally, GA and FOS enhanced the growth of Atopobium spp. after $5 \mathrm{~h}$ of fermentation compared with the baseline levels. The $C$. coccoides-Eubacterium rectale group did not change with any of the tested substrates. Additionally, Atopobium also increased after $5 \mathrm{~h}$ of fermentation of $2 \%$ FOS.

In the current study both substrates led to increases in Bacteroides spp.; these changes occurred after $5 \mathrm{~h}$ of fermentation of GA and FOS at the $1 \%$ dose $(\mathrm{p}=0.01$ and $\mathrm{p}=0.02$, respectively) and with the $2 \%$ dose of GA and FOS compared with the baseline levels ( $\mathrm{p}=$ 
2410.02 and $\mathrm{p}=0.00$, respectively). Moreover, 1\% FOS increased Bacteroides spp. after $24 \mathrm{~h}(\mathrm{p}$

$242=0.01)$. On the other hand, the prebiotic FOS at the $1 \%$ dose enhanced the growth of total

243 bacteria, achieving statistical significance after $10 \mathrm{~h}$ and $24 \mathrm{~h}$. Additionally, total bacterial

244 growth was enhanced with $2 \%$ FOS after $5 \mathrm{~h}$ compared with the negative control.

245 [Tables 3a \& 3b near here].

Impact of GA and FOS on SCFA production

247 Table (4) shows that within 1\% GA, the concentration of acetate significantly increased after $24 \mathrm{~h}$ of fermentation $(\mathrm{p} \leq 0.05)$ and exhibited an increasing trend after 5,10 , and $48 \mathrm{~h}(\mathrm{p}=$ 0.06, 0.06, and 0.08, respectively). Acetate levels were elevated at all time points after FOS fermentation compared with the levels at $0 \mathrm{~h}(\mathrm{p}=0.00,0.00,0.04$, and 0.00 , respectively), and $1 \%$ FOS led to an increase after $5 \mathrm{~h}$ compared with the negative control $(\mathrm{p}=0.01)$. Butyrate production was significantly enhanced following the fermentation of FOS between 0 and $24 \mathrm{~h}(\mathrm{p}=0.02)$ and following GA $1 \%$ fermentation after 24 and $48 \mathrm{~h}(\mathrm{p}=0.03,0.02)$; this was also the case at $24 \mathrm{~h}$ when compared with the negative control $(\mathrm{p}=0.04)$. Compared with the levels at $0 \mathrm{~h}$, propionate production increased following the fermentation of GA1\% for $48 \mathrm{~h}(\mathrm{p}=0.03)$ and the fermentation of $1 \%$ FOS for $24 \mathrm{~h}(\mathrm{p}=0.01)$.

Additionally, with 2\% FOS, acetate increased after 24 and $48 \mathrm{~h}(\mathrm{p}=0.00$ and 0.01 , respectively), and with $2 \% \mathrm{GA}$, acetate increased after $48 \mathrm{~h}$ compared with the baseline levels $(p=0.02)$. Butyrate production increased following the fermentation of $2 \%$ GA for 10 and 48 $\mathrm{h}$ compared with the levels at $0 \mathrm{~h}(\mathrm{p}=0.01$ and 0.03 , respectively). In addition, propionate increased after $10 \mathrm{~h}$ of fermentation of $2 \%$ FOS compared with the negative control $(\mathrm{p}=$ $0.04)$ and the baseline values $(p=0.01)$. 
Prior studies have noted the importance of the effect of GA on improving human health

266

(Terpend, Possemiers, Daguet and Marzorati 2013). GA is not digestible in the upper gastrointestinal tract, therefore it can reach the large intestine where it is fermented by intestinal bacteria (Adiotomre et al. 1990),(Annison et al. 1995), (Bourquin et al. 1996). Therefore this study aimed to determine the effects two doses of GA on human intestinal bacteria and to assess prebiotic potential as compared to prebiotic FOS. As such pHcontrolled batch culture fermentation systems were used to evaluate the selectivity of GA when fermented with healthy human gut microbiota compared with FOS at two different doses.

Several studies have shown that GA can undergo a slow fermentation, specifically a more distal fermentation, whereas existing prebiotics typically undergo proximal fermentation (Macfarlane et al. 1992), as proteolytic fermentation develops in the distal colon; therefore, this substrate may be able to be saccharolytically fermented in this part of colon. In this present study GA fermentation shows selectivity in bifidobacteria and Lactobacillus spp at time $10 \mathrm{~h}$ and continues to $24 \mathrm{~h}$ which could indicate slower fermentaion and is inline with others work (Cherbut, Michel1, Raison1, Kravtchenko and Severine 2003). However, it is worth noting that the bifidogenic effect of the $1 \%$ was not maintained at 48 hours in current study.

In the present study, GA significantly enhanced the growth of Bifidobacterium spp.. Bifidobacterium is considered an important group related to human health, having a favourable impact in the large intestine (Gibson and Wang 1994),(Russell et al. 2011). These results are consistent with those of Calame et al (2008) in which the consumption of $10 \mathrm{~g}$ of GA daily by healthy adults had a beneficial effect on the gut microbial composition, and increases in bifidobacteria (Calame, Weseler, Viebke, Flynn and Siemensma 2008). 
Furthermore, the $1 \%$ dose also led to increases in lactobacilli. Lactobacilli has long been considered a positive microbial group; as such, stimulation of this genera offers potential benefits to the host (Ouwehand et al. 2009). The $2 \%$ dose did not lead to the same lactobacilli impact. The use of a higher doasge could have impacted on selectivity through a cross feeding network (Guiot 1982).

Furthermore, after $10 \mathrm{~h}$, the numbers of bacteria in the $C$. histolyticum group decreased following the fermentation of $1 \% \mathrm{GA}$, which also agreed with results of in vivo studies (Wyatt et al. 1986), (Calame, Weseler, Viebke, Flynn and Siemensma 2008), (Cherbut, Michel1, Raison1, Kravtchenko and Severine 2003). This group of bacteria has sometimes been associated with inflammation and large bowel disease (Hughes 2008), (Gibson and Roberfroid 2008). It is thought that increased numbers of beneficial bacteria could lower the $\mathrm{pH}$ within the colon, therefore making the environment unfavourable for pathogenic groups; the results of the present study indicate that the fermentation of GA selectively increased the number of beneficial bacteria and reduced the number of harmful bacteria. This result further suggests the lower dose to offer improved selective potential.

In the current study GA fermentation resulted in a similar bacterial profile to FOS. Several in vivo and in vitro studies have confirmed that FOS can regulate the gut through the selective stimulation of the gut microbiota (Hidalgo et al. 2012), (Palframan et al. 2002), (Cueva et al. 2013), (Tuohy et al. 2001), therefore, GA could has potentially prebiotic properties. GA can be incorporated into baked goods, therefore could provide an alternative prebiotic source for inclusion in the diet.

Moreover, an increase in Bacteroides spp. was observed with in GA and FOS, this group is associated with a range of colonic activities (Pool-Zobel et al. 2002), (Nakamura et al. 2002). Bacteroides spp. constitute a large proportion of the microbial population in the healthy adult gastrointestinal tract (Walton 2006). In previous in vivo and in vitro studies on GA 
fermentation, increased propionate levels were associated with Bacteroides spp. and Prevotella spp. which has relevance to the improving in lipid metabolism (Frost et al. 2014),(Tulung et al. 1987).

The results show that both doses of GA were selectivly fermented. The higher dose was arguably less selective as the impact on lactobacilli and $C$. histolyticum groups were no longer apparent. In fact Calame et al (2008) noted that an increase in the concentration of substrates results in less selectivity (Calame, Weseler, Viebke, Flynn and Siemensma 2008). This might be explained by competiton for substrate, at higher dose other bacterial strains have easier access to the substrate and subsequently, become less selevtively than the lower dose.

GA fermentation induced modulation of the colonic microbiota, with increased levels of acetate, propionate, and butyrate. Acetate is produced mainly through the fructose-6phosphate phosphoketolase pathway by bifidobacteria, and the increased production of this acid could be related to increased numbers of this group (Miller and Wolin 1996). Acetate plays an important role in controlling inflammation and resisting invasion by pathogens (Rigottier-Gois et al. 2003). Propionate may be produced by Cluster IX Clostridia groups; indeed an increase in this bacterial groups was observed during GA fermentation Hosseini et al (2011). Propionate may have a direct role in central appetite regulation; increasing satiety and reducing food intake by the host (Russell et al. 2013), (Brown et al. 2003), (Chambers et al. 2015), (Cherbut et al. 1998). Whilst butyrate is often used as an energy source by epithelial cells; as such . these SCFA increases could offer benefits to the host.

The pH-controlled stirred batch culture systems enabled rapid analysis of the effects of GA on the faecal microbiota. In the absence of absorption, colonic secretions, and epithelial interactions, the system has limitations. However, processes such as SCFA production can 
still be monitored away from the impact of additionally dietary factors. Thus, batch culture systems provide an alternative way of assessing how bacteria ferment a substrate and the end products they produce (Ohashi et al. 2012).

The comparisons of the substrates in the $\mathrm{pH}$-controlled batch cultures indicated that GA has selective abilities that are at least similar to those of the known prebiotic FOS, as indicated by the bacteriology results and increased concentrations of acetate, butyrate, and propionate. These results could be relevant to improving host health by increasing the levels of the bifidobacteria group, especially in individuals with lower numbers such as elderly population. Tuohy et al (2001) reported that prebiotics can alter the gut microbiota in those with initially low numbers of bifidobacteria (Tuohy, Kolida, Lustenberger and Gibson 2001). This may be particularly relevant in elderly people. Elderly are experiencing negative changes in their gut microbiota.

\section{Conclusion}

The aim of the current study was to use in vitro batch cultures to assess the effects of GA on the microbiota compared to FOS. Here, we showed that GA modulated the gut microbiota similarly to FOS, furthermore, the $1 \%$ dose showed additional selective potential. As such GA holds the potential to be used as a novel prebiotic source.

\section{Acknowledgements:}

We thank Saudi Arabian Ministry of Education, Kingdom of Saudi Arabia for their sponsership of this study.

\section{Words count:}


References

Adiotomre J, Eastwood MA, Edwards CA, Brydon WG. 1990. Dietary fiber-In vitro methods that anticipate nutrtion and metabolic- activity in humans Am J Clin Nutr. Jul;52:128134.

Annison G, Trimble RP, Topping DL. 1995. Feeding Australian Acacia gums and gum arabic leads to non-starch polysaccharide accumulation in the cecum of rats. J Nutr. Feb;125:283-292. Epub 1995/02/01.

Babiker R, Merghani TH, Elmusharaf K, Badi RM, Lang F, Saeed AM. 2012. Effects of gum Arabic ingestion on body mass index and body fat percentage in healthy adult females: two-arm randomized, placebo controlled, double-blind trial. Nutrition journal. 2012;11:111.

Bourquin LD, Titgemeyer EC, Fahey Jr GC. 1996. Fermentation of various dietary fiber sources by human fecal bacteria. Nutrition Research. 7//;16:1119-1131. 
Brown AJ, Goldsworthy SM, Barnes AA, Eilert MM, Tcheang L, Daniels D, Muir AI, Wigglesworth MJ, Kinghorn I, Fraser NJ, et al. 2003. The Orphan G protein-coupled receptors GPR41 and GPR43 are activated by propionate and other short chain carboxylic acids. The Journal of biological chemistry. Mar 28;278:11312-11319. Epub 2002/12/24.

Calame W, Weseler AR, Viebke C, Flynn C, Siemensma AD. 2008. Gum arabic establishes prebiotic functionality in healthy human volunteers in a dose-dependent manner. Br J Nutr. Dec;100:1269-1275. Epub 2008/05/10.

Chambers ES, Viardot A, Psichas A, Morrison DJ, Murphy KG, Zac-Varghese SEK, MacDougall K, Preston T, Tedford C, Finlayson GS, et al. 2015. Effects of targeted delivery of propionate to the human colon on appetite regulation, body weight maintenance and adiposity in overweight adults. Gut. Nov;64:1744-1754.

Cherbut C, Ferrier L, Roze C, Anini Y, Blottiere H, Lecannu G, Galmiche JP. 1998. Shortchain fatty acids modify colonic motility through nerves and polypeptide YY release in the rat. Am J Physiol. Dec;275:G1415-1422. Epub 1998/12/09.

Cherbut C, Michel1 C, Raison1 V, Kravtchenko T, Severine M. 2003. Acacia Gum is a Bifidogenic Dietary Fibre with High Digestive Tolerance in Healthy Humans. Microbial Ecology in Health and Disease 2003; 15: 43/50.

Cueva C, Sanchez-Patan F, Monagas M, Walton GE, Gibson GR, Martin-Alvarez PJ, Bartolome B, Victoria Moreno-Arribas M. 2013. In vitro fermentation of grape seed flavan-3-ol fractions by human faecal microbiota: changes in microbial groups and phenolic metabolites. Fems Microbiology Ecology. Mar;83:792-805.

Daims H, Brühl A, Amann R, Schleifer K-H, Wagner M. 1999. The Domain-specific Probe EUB338 is Insufficient for the Detection of all Bacteria: Development and Evaluation of a more Comprehensive Probe Set. Syst Appl Microbiol. 9//;22:434-444.

Dauqan E, Abdullah A. 2013. Utilization of gum arabic for industries and human health. American Journal of Applied Sciences , 2013 Received 2012-11-07, Revised 201306-04; Accepted 2013-09-03;10 (10): :1270-1279.

Eckburg PB, Bik EM, Bernstein CN, Purdom E, Dethlefsen L, Sargent M, Gill SR, Nelson KE, Relman DA. 2005. Diversity of the human intestinal microbial flora. Science. Jun;308:1635-1638.

Franks AH, Harmsen HJM, Raangs GC, Jansen GJ, Schut F, Welling GW. 1998. Variations of bacterial populations in human feces measured by fluorescent in situ hybridization 
with group-specific 16S rRNA-Targeted oligonucleotide probes. Appl Environ Microbiol. Sep;64:3336-3345.

Frost G, Sleeth ML, Sahuri-Arisoylu M, Lizarbe B, Cerdan S, Brody L, Anastasovska J, Ghourab S, Hankir M, Zhang S, et al. 2014. The short-chain fatty acid acetate reduces appetite via a central homeostatic mechanism. Nature communications.5:3611. Epub 2014/05/02.

Gibson GR, Roberfroid MB. 1995. Dietary Modulation of the Human Colonie Microbiota:Introducing the Concept of Prebiotics. J Nutr.125:1401-1412.

Gibson GR, Roberfroid MB. 2008. Handbook of prebiotics. Times Cited: 0.

Gibson GR, Scott KP, Rastall RA, Tuohy KM, Hotchkiss A, Dubert-Ferrandon A, Gareau M, Murphy EF, Saulnier D, Loh G, et al. 2010. Dietary prebiotics: current status and new definition. Food Science and Technology Bulletin: Functional Foods. 2010;7:1-19.

Gibson GR, Wang X. 1994. Regulatory effects of bifidobacteria on the growth of other colonic bacteria. J Appl Bacteriol. Oct;77:412-420. Epub 1994/10/01.

Guiot HF. 1982. Role of competition for substrate in bacterial antagonism in the gut. Infect Immun. Dec;38:887-892. Epub 1982/12/01.

Harmsen HJM, Elfferich P, Schut F, Welling GW. 1999. A 16S rRNA-targeted probe for detection of lactobacilli and enterococci in faecal samples by fluorescent in situ hybridization. Microb Ecol Health Dis. March;11:3-12.

Harmsen HJM, Wildeboer-Veloo ACM, Grijpstra J, Knol J, Degener JE, Welling GW. 2000. Development of 16S rRNA-based probes for the Coriobacterium group and the Atopobium cluster and their application for enumeration of Coriobacteriaceae in human feces from volunteers of different age groups. Appl Environ Microbiol. Oct;66:4523-4527.

Hidalgo M, Oruna-Concha MJ, Kolida S, Walton GE, Kallithraka S, Spencer JPE, Gibson GR, de Pascual-Teresa S. 2012. Metabolism of Anthocyanins by Human Gut Microflora and Their Influence on Gut Bacterial Growth. J Agric Food Chem. 2012/04/18;60:3882-3890.

Hosseini E, Grootaert C, Verstraete W, Van de Wiele T. 2011. Propionate as a healthpromoting microbial metabolite in the human gut. Nutr Rev. May;69:245-258. Epub $2011 / 04 / 28$. 
Hughes S. 2008. The effect of cereal cell wall fractions on fermentation by the human gut microbiota,with a focus upon health promoting effects The University of Reading.

Kaiko GE, Stappenbeck TS. 2014. Host-microbe interactions shaping the gastrointestinal environment. Trends in Immunology. Nov;35:538-548.

Langendijk PS, Schut F, Jansen GJ, Raangs GC, Kamphuis GR, Wilkinson MHF, Welling GW. 1995. Quantitative fluorescence in-situ hybridization of bifidobacterium spp with genus-specific 16s ribosomal-rna-targeted probes and its application in fecal samples. Appl Environ Microbiol. Aug;61:3069-3075.

Macfarlane GT, Gibson GR, and, Cummings JH. 1992. Comparison of fermentation reactions in different regions of the human colon. J Appl Bacteriol.72:57-64.

Mahenran.T, Williams.P.A, Philips.G.O, AL-Assaf.S. 2008,. New Insights into the Structural Characteristics of the Arabinogalactan-Protein (AGP) Fraction of Gum Arabic. J Agric Food Chem 56,:9269-9276.

Mandalari G, Nueno-Palop C, Bisignano G, Wickham MSJ, Narbad A. 2008. Potential prebiotic properties of almond (Amygdalus communis L.) seeds. Appl Environ Microbiol. Jul;74:4264-4270.

Manz W, Amann R, Ludwig W, Vancanneyt M, Schleifer KH. (1996). Application of a suite of 16S rRNA-specific oligonucleotide probes designed to investigate bacteria of the phylum cytophaga-flavobacter-bacteroides in the natural environment. Microbiology ,.142:1097-1106.

Marzorati M, Qin B, Hildebrand F, Klosterbuer A, Roughead Z, Roessle C, Rochat F, Raes J, Possemiers S. 2015. Addition of acacia gum to a FOS/inulin blend improves its fermentation profile in the Simulator of the Human Intestinal Microbial Ecosystem (SHIME®). J Funct Foods. 6//;16:211-222.

Miller TL, Wolin MJ. 1996. Pathways of acetate, propionate, and butyrate formation by the human fecal microbial flora. Appl Environ Microbiol. May;62:1589-1592.

Mills DJS, Tuohy KM, Booth J, Buck M, Crabbe MJC, Gibson GR, Ames JM. 2008. Dietary glycated protein modulates the colonic microbiota towards a more detrimental composition in ulcerative colitis patients and non-ulcerative colitis subjects.

Nakamura J, Kubota Y, Miyaoka M, Saitoh T, Mizuno F, Benno Y. 2002. Comparison of four microbial enzymes in Clostridia and Bacteroides isolated from human feces. Microbiology and immunology.46:487-490. Epub 2002/09/12. 
Ohashi Y, Harada K, Tokunaga M, Ishihara N, Okubo T, Ogasawara Y, Juneja LR, Fujisawa T. 2012. Faecal fermentation of partially hydrolyzed guar gum. J Funct Foods. Jan;4:398-402.

Ouwehand AC, Tiihonen K, Saarinen M, Putaala H, Rautonen N. 2009. Influence of a combination of Lactobacillus acidophilus NCFM and lactitol on healthy elderly: intestinal and immune parameters. Br J Nutr. Feb;101:367-375. Epub 2008/07/19.

Palframan RJ, Gibson GR, Rastall RA. 2002. Effect of pH and Dose on the Growth of Gut Bacteria on Prebiotic Carbohydrates in vitro. anaerob. 10//;8:287-292.

Pool-Zobel B, van Loo J, Rowland I, Roberfroid MB. 2002. Experimental evidences on the potential of prebiotic fructans to reduce the risk of colon cancer. Br J Nutr. May;87 Suppl 2:S273-281. Epub 2002/06/29.

Richardson AJ, Calder AG, Stewart CS, Smith A. 1989. Simultaneous determination of volatile and non-volatile acidic fermentation products of anaerobes by capillary gas chromatography. Letters in Applied Microbiology.9:5-8.

Rigottier-Gois L, Rochet V, Garrec N, Suau A, Dore J. 2003. Enumeration of Bacteroides species in human faeces by fluorescent in situ hybridisation combined with flow cytometry using 16S rRNA probes. Syst Appl Microbiol. Mar;26:110-118. Epub 2003/05/16.

Russell DA, Ross RP, Fitzgerald GF, Stanton C. 2011. Metabolic activities and probiotic potential of bifidobacteria. Int J Food Microbiol. Sep 1;149:88-105. Epub 2011/07/19.

Russell WR, Hoyles L, Flint HJ, Dumas ME. 2013. Colonic bacterial metabolites and human health. Current opinion in microbiology. Jun;16:246-254. Epub 2013/07/25.

Steer TE, Johnson IT, Gee JM, Gibson GR. 2003. Metabolism of the soyabean isoflavone glycoside genistin in vitro by human gut bacteria and the effect of prebiotics. B J Nutr. Sep;90:635-642.

Terpend K, Possemiers S, Daguet D, Marzorati M. 2013. Arabinogalactan and fructooligosaccharides have a different fermentation profile in the Simulator of the Human Intestinal Microbial Ecosystem (SHIME®). Environmental Microbiology Reports.n/a-n/a.

Tolhurst G, Heffron H, Lam YS, Parker HE, Habib AM, Diakogiannaki E, Cameron J, Grosse J, Reimann F, Gribble FM. 2012. Short-chain fatty acids stimulate glucagon- 

like peptide-1 secretion via the G-protein-coupled receptor FFAR2. Diabetes. Feb;61:364-371. Epub 2011/12/23.

Tulung B, Remesy C, Demigne C. 1987. Specific effect of guar gum or gum arabic on adaptation of cecal digestion to high fiber diets in the rat. J Nutr. Sep;117:1556-1561. Epub 1987/09/01.

Tuohy KM, Kolida S, Lustenberger AM, Gibson GR. 2001. The prebiotic effects of biscuits containing partially hydrolysed guar gum and fructo-oligosaccharides - a human volunteer study. B J Nutr. Sep;86:341-348.

Verbeken D, Dierckx S, Dewettinck K. 2003. Exudate gums: occurrence, production, and applications. Appl Microbiol Biotechnol. Nov;63:10-21. Epub 2003/06/13.

Walton GE. 2006. The bacterial metabolism of dietary prebiotics and the potential for protection against colorectal cancer - University of Reading, .

Williams P, Phillips G. 2000. . Handbook of Hydrocolloids: CRC Press, Boca Raton, FL, pp.

Wyatt GM, Bayliss CE, Holcroft JD. 1986. A change in human fecal flora in response to inclusion of gum arabic in the diet B J Nutr. Mar;55:261-266.

Table 1: Composition and nutritional profile of GA used in the present study

\begin{tabular}{ll}
\hline Analysis & Results \\
\hline Energy (kcal) & $1205 \mathrm{~kJ} / 100 \mathrm{~g}$ \\
Protein & $2.1 \mathrm{~g} / 100 \mathrm{~g}$ \\
Total carbohydrate (by difference) & $82.6 \mathrm{~g} / 100 \mathrm{~g}$ \\
Carbohydrate (avail) & $56.5 \mathrm{~g} / 100 \mathrm{~g}$ \\
Total Suger* & $0.6 \mathrm{~g} / 100 \mathrm{~g}$ \\
Fibre & $26.1 \mathrm{~g} / 100 \mathrm{~g}$ \\
Fat & $0.1 \mathrm{~g} / 100 \mathrm{~g}$ \\
Sodium & $11.0 \mathrm{mg} / 100 \mathrm{~g}$ \\
Moisture & $11.8 \mathrm{~g} / 100 \mathrm{~g}$ \\
Ash & $3.49 \mathrm{~g} / 100 \mathrm{~g}$ \\
\hline
\end{tabular}


609 Table 2 : Hybridisation and washing conditions for oligonucleotide probes

\begin{tabular}{|l|l|l|l|l|l|l|}
\hline $\begin{array}{l}\text { Probe } \\
\text { name }\end{array}$ & Sequence (5' to 3') & $\begin{array}{l}\text { Hybridisation } \\
\text { pre-treatment }\end{array}$ & $\begin{array}{l}\text { Formamid } \\
\text { e } \%) \text { in } \\
\text { hybridisat } \\
\text { ion buffer }\end{array}$ & $\begin{array}{l}\text { Hybridisati } \\
\text { on } \\
\text { temperature } \\
\left({ }^{\circ} \mathrm{C}\right)\end{array}$ & $\begin{array}{l}\text { Washing } \\
\text { temperatur } \\
\text { e }\left({ }^{\circ} \mathrm{C}\right)\end{array}$ & Reference \\
\hline Ato 291 & GGTCGGTCTCTCAACCC & Lysozyme & 0 & 50 & 50 & $\begin{array}{l}\text { (Harmsen et } \\
\text { al. 2000) }\end{array}$ \\
\hline Lab 158 & GGTATTAGCAYCTGTTTCCA & Lysozyme & 0 & 50 & 50 & $\begin{array}{l}\text { (Harmsen et } \\
\text { al. 1999) }\end{array}$ \\
\hline Bif 164 & CATCCGGCATTACCACCC & Lysozyme & 0 & 50 & 50 & $\begin{array}{l}\text { (Langendijk } \\
\text { et al. 1995) }\end{array}$ \\
\hline Erec 482 & GCTTCTTAGTCARGTACCG & None & 0 & 50 & 50 & $\begin{array}{l}\text { (Franks et } \\
\text { al. 1998) }\end{array}$ \\
\hline Chis 150 & TTATGCGGTATTAATCTYCCTTT & None & 0 & 50 & 50 & $\begin{array}{l}\text { (Franks, } \\
\text { Harmsen, } \\
\text { Raangs, } \\
\text { Jansen, } \\
\text { Schut } \\
\text { Welling } \\
\text { and }\end{array}$ \\
\hline
\end{tabular}




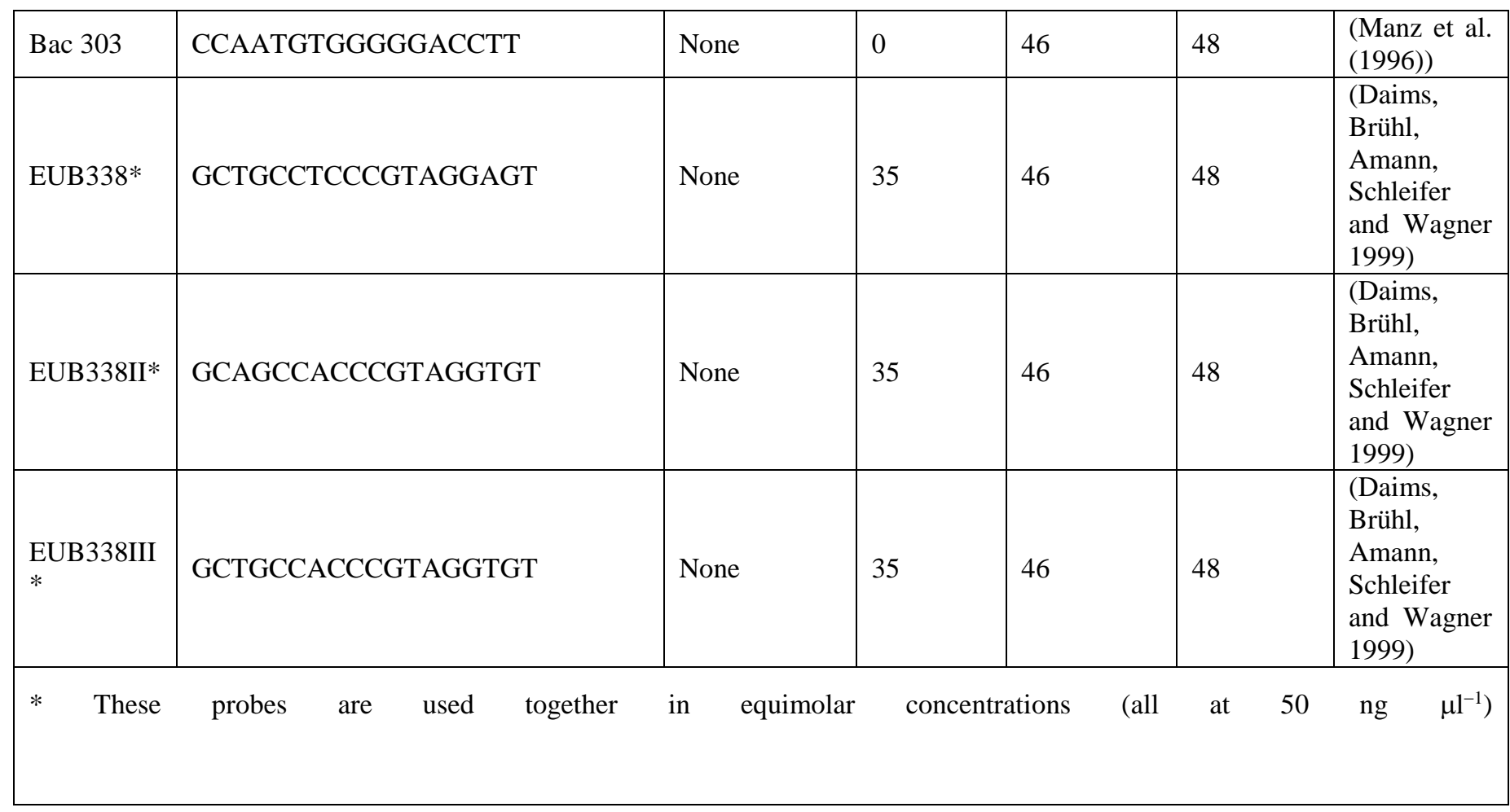

610

611

612

613 


\begin{tabular}{|c|c|c|c|c|c|c|c|c|c|c|c|c|c|c|}
\hline & \multicolumn{2}{|l|}{ Bif164 } & \multicolumn{2}{|l|}{ Lab158 } & \multicolumn{2}{|l|}{ Ato291 } & \multicolumn{2}{|l|}{ Bac303 } & \multicolumn{2}{|c|}{ Erec482 } & \multicolumn{2}{|c|}{ Chis150 } & \multicolumn{2}{|c|}{ EubI-II-III } \\
\hline & mean & SD & mean & SD & mean & SD & mean & SD & mean & SD & mean & SD & mean & SD \\
\hline Control 0h & 7.46 & 0.21 & 7.24 & 0.09 & 7.40 & 0.18 & 7.85 & 0.24 & 7.96 & 0.20 & 6.91 & 0.24 & 8.26 & 0.35 \\
\hline Control 5h & 7.76 & 0.20 & 7.29 & 0.07 & 7.60 & 0.15 & 8.04 & 0.20 & 7.36 & 0.07 & 6.42 & 0.38 & 8.45 & 0.08 \\
\hline Control 10h & 7.75 & 0.24 & 7.47 & 0.07 & 7.56 & 0.02 & 8.25 & 0.28 & 7.51 & 0.07 & 6.99 & 0.16 & 8.44 & 0.04 \\
\hline Control 24h & 7.78 & 0.16 & 7.29 & 0.04 & 7.54 & 0.14 & 8.12 & 0.21 & 7.54 & 0.08 & 5.73 & 0.47 & 8.53 & 0.36 \\
\hline Control 48h & 7.64 & 0.29 & 7.14 & 0.50 & 7.50 & 0.61 & 7.76 & 0.17 & 7.51 & 0.06 & 5.68 & 0.73 & 8.42 & 0.18 \\
\hline FOS 0h & 7.39 & 0.21 & 7.31 & 0.08 & 7.52 & 0.09 & 7.80 & 0.11 & 7.72 & 0.2 & 6.62 & 0.53 & 8.21 & 0.14 \\
\hline FOS $5 \mathrm{~h}$ & $7.83 *$ & 0.06 & $7.78 * *$ & 0.04 & $7.83 *$ & 0.10 & $8.16 *$ & 0.09 & 7.41 & 0.16 & $5.71 *$ & 0.55 & 8.78 & 0.11 \\
\hline FOS 10h & 8.00 & 0.07 & $7.53 * *$ & 0.09 & 7.77 & 0.30 & 8.30 & 0.10 & 7.83 & 0.29 & 6.23 & 1.09 & $8.72 *$ & 0.08 \\
\hline FOS $24 h$ & 8.17 & 0.23 & $7.75 *$ & 0.14 & 7.79 & 0.31 & $8.24 *$ & 0.01 & 7.50 & 0.12 & 6.27 & 0.88 & $8.83 *$ & 0.14 \\
\hline FOS 48h & 7.82 & 0.15 & 7.44 & 0.15 & 7.58 & 0.18 & 7.93 & 0.18 & 7.28 & 0.19 & 5.65 & 0.69 & 8.57 & 0.17 \\
\hline GUM 0h & 7.53 & 0.10 & 7.00 & 0.16 & 7.43 & 0.05 & 7.70 & 0.22 & 7.81 & 0.37 & 6.08 & 0.50 & 8.29 & 0.22 \\
\hline GUM 5h & $7.92 *$ & 0.11 & $7.32 *$ & 0.05 & $7.80 * *$ & 0.06 & $7.97 *$ & 0.19 & 7.42 & 0.11 & 6.64 & 0.42 & 8.54 & 0.18 \\
\hline GUM 10h & $7.90 *$ & 0.14 & 7.46 & 0.11 & 7.60 & 0.26 & 8.01 & 0.35 & 7.44 & 0.166 & $5.87 *$ & 0.82 & 8.79 & 0.71 \\
\hline GUM 24h & $7.93 *$ & 0.06 & $7.59 * *$ & 0.22 & 7.66 & 0.22 & 8.08 & 0.52 & 7.65 & 0.17 & 5.87 & 0.82 & 8.53 & 0.25 \\
\hline GUM 48h & $7.22 \mathbf{a}$ & 0.37 & 7.39 & 0.11 & 7.53 & 0.40 & 8.20 & 0.24 & 7.39 & 0.49 & 6.28 & 0.86 & 8.49 & 0.56 \\
\hline
\end{tabular}


Table 3-b: changes in the bacterial composition figures are presenting the mean bacterial populations in $\mathrm{pH}$-controlled batch cultures at 0,5 , 10, 24 , 616 and $48 \mathrm{~h}$.Values are mean $\pm \mathrm{SD} . *$, significant differences from the $0 \mathrm{~h}$ value within the same treatment, $\mathrm{p}<0.05$. small letters differences from the negative control. $1 \%$ faecal batch culture inoculated with vessel 1 negative control, vessel 2 FOS 1\%, vessel 3 FOS $2 \%$, vessel 4 GA $1 \%$, vessel 5 GA $6172 \%$.

\begin{tabular}{|c|c|c|c|c|c|c|c|c|c|c|c|c|c|c|}
\hline & \multicolumn{2}{|c|}{ Bif164 } & \multicolumn{2}{|c|}{ Lab158 } & \multicolumn{2}{|c|}{ Ato291 } & \multicolumn{2}{|c|}{ Bac303 } & \multicolumn{2}{|c|}{ Erec482 } & \multicolumn{2}{|c|}{ Chis150 } & \multicolumn{2}{|c|}{ EubI-II-III } \\
\hline & mean & SD & mean & SD & mean & SD & mean & SD & mean & SD & mean & SD & mean & SD \\
\hline Control 0h & 7.46 & 0.21 & 7.24 & 0.09 & 7.40 & 0.18 & 7.85 & 0.24 & 7.96 & 0.20 & 6.91 & 0.24 & 8.26 & 0.35 \\
\hline Control 5h & 7.76 & 0.20 & 7.29 & 0.07 & 7.60 & 0.15 & 8.04 & 0.20 & 7.36 & 0.07 & 6.42 & 0.38 & 8.45 & 0.08 \\
\hline Control 10h & 7.75 & 0.24 & 7.47 & 0.07 & 7.56 & 0.02 & 8.25 & 0.28 & 7.51 & 0.07 & 6.99 & 0.16 & 8.44 & 0.04 \\
\hline Control 24h & 7.78 & 0.16 & 7.29 & 0.04 & 7.54 & 0.14 & 8.12 & 0.21 & 7.54 & 0.08 & 5.73 & 0.47 & 8.53 & 0.36 \\
\hline Control 48h & 7.64 & 0.29 & 7.14 & 0.50 & 7.50 & 0.61 & 7.76 & 0.17 & 7.51 & 0.06 & 5.68 & 0.73 & 8.42 & 0.18 \\
\hline FOS 0h & 7.4 & 0.1 & 7.24 & 0.24 & 7.57 & 0.10 & 7.89 & 0.17 & 7.84 & 0.27 & 6.44 & 0.51 & 8.35 & 0.29 \\
\hline FOS $5 \mathrm{~h}$ & $7.93 *$ & 0.15 & $7.75 \mathbf{a}$ & 0.14 & $7.98 * *$ & 0.12 & $8.38 *$ & 0.02 & 7.74 & 0.3 & 6.45 & 0.40 & $8.89 \mathbf{a}$ & 0.083 \\
\hline FOS 10h & 8.02 & 0.11 & 7.58 & 0.14 & 7.89 & 0.18 & 7.8 & 0.32 & 7.88 & 0.19 & 6.25 & 0.94 & 8.76 & 0.26 \\
\hline FOS $24 h$ & $8.12 \mathbf{a}$ & 0.17 & $7.51 \mathbf{a}$ & 0.1 & 7.81 & 0.19 & 8.07 & 0.3 & 7.82 & 0.19 & 5.88 & 0.85 & 8.56 & 0.08 \\
\hline FOS $48 \mathrm{~h}$ & 7.88 & 0.11 & 7.43 & 0.15 & 7.67 & 0.10 & 7.95 & 0.34 & 7.62 & 0.18 & 5.87 & 0.15 & 8.69 & 0.29 \\
\hline GUM 0h & 7.33 & 0.05 & 7.38 & 0.14 & 7.58 & 0.18 & 7.73 & 0.22 & 7.77 & 0.2 & 6.39 & 0.58 & 8.11 & 0.17 \\
\hline GUM 5h & $7.78 * *$ & 0.06 & 7.32 & 0.13 & 7.67 & 0.29 & $8.01 * *$ & 0.23 & 7.6 & 0.16 & 6.31 & 0.67 & 8.44 & 0.16 \\
\hline GUM 10h & $7.98 *$ & 0.13 & 7.6 & 0.31 & 7.70 & 0.25 & 8.21 & 0.54 & 7.58 & 0.2 & 6.09 & 0.75 & 8.74 & 0.47 \\
\hline GUM 24h & 7.93 & 0.28 & 7.67 & 0.27 & 7.66 & 0.26 & 8.17 & 0.3 & 7.68 & 0.29 & 6.57 & 0.73 & 8.72 & 0.18 \\
\hline GUM 48h & 7.69 & 0.149 & 7.34 & 0.12 & 7.78 & 0.27 & 8.2 & 0.25 & 7.46 & 0.3 & 6.04 & 0.91 & $8.66 *$ & 0.17 \\
\hline
\end{tabular}


618 Table 4: changes in the SCFA concentration are presenting in table 3 in $\mathrm{pH}$-controlled batch cultures at $0,5,10,24$, and $48 \mathrm{~h}$.Values are mean \pm SD. $*$, significant differences from the $0 \mathrm{~h}$ 619 value within the same treatment, $\mathrm{p}<0.05$. small letters differences from the negative control. $1 \%$ faecal batch culture inoculated with vessel 1 negative control, vessel 2 FOS 1\%, vessel 3 FOS 621 $2 \%$, vessel 4 GA $1 \%$, vessel 5 GA $2 \%$.

\begin{tabular}{|c|c|c|c|}
\hline & ACETATE & PROPIONATE & BUTYRATE \\
\hline \multicolumn{4}{|c|}{ Control } \\
\hline $0 \mathrm{~h}$ & $1.68 \pm 1.16$ & $0.19 \pm 0.12$ & $0.15 \pm 0.09$ \\
\hline $5 \mathrm{~h}$ & $4.49 \pm 0.99 a$ & $0.82 \pm 0.86$ & $2.15 \pm 3.19$ \\
\hline $10 \mathrm{~h}$ & $6.47 \pm 1.34$ & $2.51 \pm 1.19 \mathrm{a}$ & $1.47 \pm 0.35$ \\
\hline $24 \mathrm{~h}$ & $8.88 \pm 1.71$ & $4.50 \pm 2.29$ & $1.73 \pm 0.85 \mathrm{a}$ \\
\hline $48 \mathrm{~h}$ & $10.57 \pm 3.57$ & $5.40 \pm 3.11$ & $3.10 \pm 2.41$ \\
\hline \multicolumn{4}{|c|}{ FOS 1\% } \\
\hline $0 \mathrm{~h}$ & $0.98 \pm 0.04$ & $0.10 \pm 0.03$ & $0.08 \pm 0.02$ \\
\hline $5 \mathrm{~h}$ & $8.84 \pm 3.53 * * \mathrm{a}$ & $1.86 \pm 0.31$ & $0.66 \pm 0.24$ \\
\hline $10 \mathrm{~h}$ & $13.12 \pm 2.02 * *$ & $8.45 \pm 6.98$ & $4.42 \pm 2.02$ \\
\hline $24 \mathrm{~h}$ & $11.89 \pm 4.22 *$ & $8.13 \pm 2.10 *$ & $8.26 \pm 2.98 *$ \\
\hline $48 \mathrm{~h}$ & $10.00 \pm 1.11 * *$ & $4.32 \pm 3.42$ & $1.21 \pm 1.58$ \\
\hline \multicolumn{4}{|c|}{ FOS 2\% } \\
\hline $0 \mathrm{~h}$ & $1.35 \pm 0.26$ & $0.19 \pm 0.10$ & $0.13 \pm 0.06$ \\
\hline $5 \mathrm{~h}$ & $14.28 \pm 4.93$ & $4.24 \pm 3.54$ & $2.32 \pm 2.10$ \\
\hline $10 \mathrm{~h}$ & $15.08 \pm 2.93$ & $5.80 \pm 1.04 * \mathrm{a}$ & $5.93 \pm 4.34$ \\
\hline $24 \mathrm{~h}$ & $13.00 \pm 7.81 * *$ & $5.44 \pm 2.56$ & $6.21 \pm 4.05$ \\
\hline $48 \mathrm{~h}$ & $8.80 \pm 0.32 *$ & $2.31 \pm 1.85$ & $3.66 \pm 1.52$ \\
\hline \multicolumn{4}{|c|}{ GUM $1 \%$} \\
\hline $0 \mathrm{~h}$ & $2.01 \pm 1.73$ & $0.18 \pm 0.10$ & $0.16 \pm 0.12$ \\
\hline $5 \mathrm{~h}$ & $5.36 \pm 0.37$ & $4.79 \pm 4.76$ & $4.99 \pm 7.61$ \\
\hline $10 \mathrm{~h}$ & $12.72 \pm 4.79$ & $6.77 \pm 4.78$ & $6.96 \pm 7.79$ \\
\hline $24 \mathrm{~h}$ & $10.78 \pm 8.27$ & $3.28 \pm 2.61$ & $4.59 \pm 1.49 * \mathrm{a}$ \\
\hline $48 \mathrm{~h}$ & $11.64 \pm 4.10 *$ & $4.79 \pm 1.46 *$ & $4.01 \pm 0.88 *$ \\
\hline \multicolumn{4}{|c|}{ GUM $2 \%$} \\
\hline $0 \mathrm{~h}$ & $2.37 \pm 2.29$ & $0.19 \pm 0.12$ & $0.16 \pm 0.12$ \\
\hline $5 \mathrm{~h}$ & $5.24 \pm 0.56$ & $5.13 \pm 5.93$ & $0.73 \pm 0.42$ \\
\hline $10 \mathrm{~h}$ & $16.67 \pm 7.59$ & $12.03 \pm 8.32$ & $2.40 \pm 0.51$ \\
\hline $24 \mathrm{~h}$ & $11.41 \pm 9.15$ & $3.28 \pm 2.51$ & $3.09 \pm 2.49 *$ \\
\hline $48 \mathrm{~h}$ & $13.63 \pm 3.17 *$ & $6.15 \pm 2.24$ & $6.24 \pm 2.22 *$ \\
\hline
\end{tabular}

